\title{
FORMULASI SEDIAAN KRIM ANTI LUKA BAKAR DARI EKSTRAK AIR DAGING DAUN ALOE VERA
}

\author{
P. O. Samirana, N. W. Satriani, P. R. Harfa, S. P. P. Dewi, C. I. S. Arisanti* \\ Program Studi Farmasi Fakultas Matematika dan Ilmu Pengetahuan Alam Universitas Udayana \\ Jalan Kampus Unud-Jimbaran, Jimbaran-Bali, Indonesia 80364 Telp/Fax: 703837 \\ "Email: cokorda_arisanti@unud.ac.id
}

\begin{abstract}
ABSTRAK
Lidah buaya (Aloe vera) merupakan salah satu tanaman yang secara empiris sering digunakan untuk menyembuhkan luka bakar. Ekstrak air daging daun Aloe vera mengandung saponin dan flavonoid, di samping itu juga mengandung tanin dan polifenol. Penelitian ini dilakukan untuk mengetahui apakah ekstrak air daging daun aloe vera yang diperoleh telah memenuhi parameter standar mutu ekstrak sehingga dapat digunakan dalam formulasi. Tahapan yang dilakukan yaitu ekstraksi daging daun aloe vera dengan metode maserasi infundasi, Standarisasi ekstrak air daging lidah buaya meliputi pengujian penetapan susut pengeringan, kadar abu total, penetapan kadar abu tidak larut dalam asam, penetapan kadar sari yang larut dalam air, penetapan kadar sari yang larut dalam etanol dan skrining fito kimia, identifikasi dengan FT-IR, pembuatan sediaan krim, evaluasi sediaan krim. Ekstrak air daging daun lidah buaya diperoleh dengan teknik infudasi. Pengujian susut pengeringan ekstrak yang dihasilkan sebesar 26,33 \%, kadar abu total sebesar 1,3\%, kadar sari larut dalam air sebesar $11,9 \%$ dan kadar sari larut etanol 12,01\%, kadar flavonoid total sebesar 2,9\%.
\end{abstract}

Kata kunci: Aloe Vera, Formulasi, Krim, Luka Bakar.

\begin{abstract}
Aloe vera (Aloe vera) is a plant that is empirically often used to heal burns. Aloe vera leaf meat water extract contains saponins and flavonoids, in addition it also contains tannins and polyphenols. This research was conducted to determine whether the extracted water of Aloe vera leaf meat had met the parameters of extract quality standards so that it could be used in formulations. The steps taken are the extraction of aloe vera leaf meat with the method of infundation maceration, standardization of Aloe vera meat water extraction including testing the determination of drying shrinkage, total ash content, determination of ash content which is insoluble in acid, determination of the essence of water soluble extract, determination of the extract soluble in ethanol and chemical screening, identification with FT-IR, preparation of cream preparations, evaluation of cream preparations. Aloe vera leaf meat extract was obtained by infudation technique. Tests for drying drying extract produced $26.33 \%$, total ash content of $1.3 \%$, water soluble extract content of $11.9 \%$ and ethanol soluble extract content of $12.01 \%$, total flavonoid content of $2.9 \%$.
\end{abstract}

Keywords: Aloe Vera, Formulation, Cream, Burns.

\section{PENDAHULUAN}

Luka bakar merupakan suatu bentuk kerusakan atau kehilangan jaringan yang disebabkan kontak dengan sumber panas seperti api, air panas, listrik, radiasi atau zat korosif. Tingkat keparahan cedera biasanya ditandai dengan luasnya kulit yang terkena, lokasi anatomis, kedalaman cedera, usia pasien dan adanya kelainan penyerta (Stylianou et al., 2014). Beban cedera akibat kasus luka bakar adalah salah satu faktor utama yang memberikan dampak terhadap psikologis, sosial, dan ekonomi bagi pasien maupun keluarga pasien. Secara umum cedera luka bakar menyebabkan perawatan yang berkepanjangan, membutuhkan biaya pengobatan yang tinggi, tata laksana yang kompleks, waktu penyembuhan yang lama, dan timbulnya bekas luka fisik yang bersifat permanen juga menjadi masalah yang harus diterima oleh pasien (Peck et al., 2009).

Sediaan topikal yang sering digunakan pada kasus luka bakar derajat I dan II adalah krim silver sulfadiazine yang hanya mengandung antibiotik (Atiyeh et al., 2006). Krim silver sulfadiazine dapat menghambat peran fibroblas dalam proses penutupan luka 
dan dapat menyebabkan leukopenia selama minggu pertama setelah cedera (Monafo, 2009; Thomas et al., 2009). Pengobatan dengan obat dari bahan alam menjadi alternatif yang dapat dikembangkan untuk mengatasi masalah ini, karena dianggap lebih aman dibandingkan penggunaan obat sintetis, karena memiliki efek samping yang relatif lebih kecil jika digunakan secara tepat yang meliputi kebenaran bahan, ketepatan dosis, ketepatan waktu penggunaan, ketepatan cara penggunaan, ketepatan telaah informasi, dan tanpa penyalahgunaan obat bahan alam itu sendiri (Sari, 2006).

Lidah buaya (Aloe vera) merupakan salah satu tanaman yang secara empiris dapat digunakan untuk menyembuhkan luka bakar. Ekstrak air daging daun Aloe vera mengandung saponin dan flavonoid,mengandung tanin dan polifenol. Saponin dapat digunakan sebagai pembersih sehingga efektif untuk menyembuhkan luka terbuka, sedangkan tanin dapat digunakan sebagai pencegahan terhadap infeksi luka karena mempunyai daya antiseptik dan obat luka bakar. Flavonoid dan polifenol mempunyai aktivitas sebagai antiseptik (Harborne, 1987).

Berdasarkan uraian diatas maka ingin dilakukan penelitian terhadap ekstrak air lidah buaya untuk mengetahui apakah ekstrak air daging daun aloe vera yang diperoleh telah memenuhi parameter standar mutu ekstrak sehingga dapat digunakan dalam formulasi.

\section{MATERI DAN METODE}

Bahan

Bahan yang digunakan pada penelitian ini Aloe vera, Cera alba, Natrium benzoate, Setil alkohol, Span 80, Paraffin liquidum, Metilparaben, Propilparaben, Akuades, $\mathrm{FeCl}_{3}$ $5 \%, \mathrm{HCl} 2 \mathrm{~N}$, Larutan Sudan III.

\section{Alat \\ Pisau, Oven, Water bath, Cawan porselen, Blender, Alat-alat gelas, Alat uji daya lekat, Viknometer, Magnetic stirrer, Alat uji daya lekat sebar, Neraca analitik, Saringan, Sendok tanduk, Mortar dan stamper.}

\section{Cara Kerja}

\section{Formula krim aloe vera}

Pada penelitian ini digunakan formula sebagai berikut:
Tabel 1. Formulasi Krim

\begin{tabular}{lc}
\hline BAHAN & $\begin{array}{c}\text { Konsentrasi } \\
\text { bahan }\end{array}$ \\
\hline Cera alba & $16 \%$ \\
Parafin cair & $45 \%$ \\
Span 80 & $5 \%$ \\
Metilparaben & $0,1 \%$ \\
Propilparaben & $0,2 \%$ \\
Ekstrak daging aloe vera & $15 \%$ \\
Akuades ad & $100 \%$ \\
\hline
\end{tabular}

\section{Ekstraksi Daging Daun Lidah Buaya}

Sampel lidah buaya diperoleh dicuci dengan air mengalir, dipotong pangkalnya 5 $\mathrm{cm}$ lalu di ukuran diperkecil dengan dipotong dan dikupas kulitnya (kulit daun dibuang). Daging lidah buaya ditimbang sebanyak 1600 $\mathrm{g}$ dan diblender, selanjutnya dilarutkan dengan air (dengan perbandingan 1:1). Lidah buaya diekstraksi dengan teknik infudasi. Lidah buaya diblender kemudian panaskan dengan suhu $70^{\circ} \mathrm{C}$ selama 15 menit, kemudian disaring dan selanjutnya dipekatkan sampai menjadi ekstrak kental (Wirya, 2012; Wijaya dkk., 2013).

\section{Standarisasi ekstrak}

Standarisasi ekstrak daging daun lidah buaya meliputi pengujian penetapan susut pengeringan, penetapan kadar abu total,. abu tidak larut dalam asam, sari yang larut dalam etanol, sari yang larut dalam air, dan skrining fitokimia.

\section{Penetapan susut pengeringan}

Botol timbang dipanaskan pada suhu penetapan selama 30 menit. Kemudian ditimbang sebanyak $1 \mathrm{~g}$ dan $2 \mathrm{~g}$ zat dalam botol timbang tertutup tersebut. Digoyangkan botol agar zat dalam botol timbang merata, hingga merupakan lapisan setebal lebih kurang $5 \mathrm{~mm}$ sampai $10 \mathrm{~mm}$, dimasukkan ke ruang pengering, tutup dibuka, dikeringkan pada suhu penetapan hingga bobot tetap. Jika suhu lebur zat lebih rendah dari suhu penetapan, pengeringan dilakukan pada suhu antara $5^{\circ}$ dan $10^{\circ} \mathrm{C}$ dibawah suhu leburnya selama 1 jam sampai 2 jam, kemudian pada suhu penetapan selama waktu yang ditentukan atau hingga bobot tetap (Depkes RI, 1995a). 


\section{Penetapan kadar abu total}

Sebanyak $3 \mathrm{~g}$ zat digerus lalu ditimbang saksama, dimasukkan ke dalam krus silikat yang telah dipijarkan dan ditara, lalu diratakan. Perlahan-lahan dipijarkan hingga arang habis, kemudian didinginkan dan ditimbang. Bila dengan cara tersebut arang tidak dapat dihilangkan, maka ditambahkan air panas, disaring dengan kertas saring bebas abu. Sisa dan kertas saring dipijarkan dalam krus yang sama. Dimasukkan filtrat ke dalam krus, diuapkan, dipijarkan hingga bobot tetap, ditimbang. Dihitung kadar abu terhadap bahan yang telah dikeringkan di udara.

\section{Penetapan Kadar Abu yang Tidak Larut dalam Asam}

Dididihkan dengan $25 \mathrm{~mL}$ asam klorida encer P selama 5 menit abu yang telah diperoleh pada penetapan kadar abu, bagian yang tidak larut dalam asam dikumpulkan. Selanjutnya disaring melalui krus kaca masir atau kertas saring bebas abu, dicuci dengan air panas, dipanaskan hingga bobot tetap, ditimbang. Kadar abu yang tidak larut dalam asam terhadap bahan yang telah dikeringkan di udara dihitung (Depkes RI, 1995a)

\section{Penetapan Kadar Sari yang Larut dalam Air}

Penetapan kadar sari yang larut dalam air dilakukan dengan cara serbuk dikeringkan di udara, dimaserasi dalam waktu 24 jam $5 \mathrm{~g}$ serbuk dalam $100 \mathrm{~mL}$ air kloroform $\mathrm{P}$, menggunakan labu ukur sambil dikocok selama 6 jam pertama dan kemudian dibiarkan selama 18 jam. Disaring, $20 \mathrm{ml}$ filtrat diuapkan hingga kering dalam cawan yang telah ditara, dipanaskan pada suhu $105^{\circ} \mathrm{C}$ hingga bobot tetap. Kadar dalam persen sari yang larut dalam air dihitung terhadap bahan yang telah dikeringkan di udara (Depkes RI, 1995a).

\section{Penetapan Kadar Sari yang Larut dalam Etanol}

Serbuk dikeringkan di udara, dimaserasi selama 24 jam 5,0 g serbuk dengan $100 \mathrm{~mL}$ etanol (95\%), menggunakan labu ukur sambil dikocok selama 6 jam pertama dan kemudian dibiarkan selama 18 jam. Disaring cepat dengan menghindarkan penguapan etanol (95\%), diuapkan $20 \mathrm{~mL}$ filtrat hingga kering dalam cawan yang telah ditara, dipanaskan pada suhu $105^{\circ} \mathrm{C}$ hingga bobot tetap. Kadar dalam persen sari yang larut dalam etanol $(95 \%)$ dihitung terhadap bahan yang telah dikeringkan di udara (Depkes RI, 1995a).

\section{Skrining Fitokimia}

Dilakukan skrining fitokimia meliputi uji saponin, tanin dan flavonoid.

\section{Pembuatan Larutan Uji Skrining Fitokimia}

Sebanyak $100 \mathrm{mg}$ ekstrak air Aloe vera dilarutkan dalam $10 \mathrm{~mL}$ etanol $70 \%$ (Dewi dkk., 2013).

\section{Identifikasi Saponin}

Dimasukan $10 \mathrm{~mL}$ larutan uji dalam tabung reaksi kemudian dikocok vertikal selama 10 detik lalu dibiarkan selama 10 detik. Terbentuknya busa setinggi $1-10 \mathrm{~cm}$ yang stabil selama tidak lebih dari10 menit dan penambahan 1 tetes $\mathrm{HCl} 2 \mathrm{~N}$, busa tidak hilang menunjukkan adanya saponin (Depkes RI, 1995b).

\section{Identifikasi Tanin}

Uji tanin dilakukan dengan melarutkan $5 \mathrm{mg}$ ekstrak Aloe vera dengan $10 \mathrm{~mL}$ akuades dan sibagi ke dalam dua tabung reaksi. Tabung 1 ditambahkan beberapa tetes larutan besi (III) klorida 5\%, terbentuknya warna biru kehijauan menunjukkan adanya tanin. Tabung 2 ditambahkan tiga tetes Timbal (II) asetat, hasil positif menunjukkan terbentuk endapan purih (Vijayalakshmi and Ravindhran, 2012).

\section{Identifikasi Flavonoid}

Sebanyak $1 \mathrm{ml}$ larutan uji diuapkan, basahkan sisanya dengan aseton $P$, ditambahkan sedikit serbuk halus asam borat $\mathrm{P}$ dan serbuk halus asam oksalat $\mathrm{P}$, dipanaskan di atas tangas air dan hindari pemanasan berlebihan. Eter $\mathrm{P}$ ditambahkan $10 \mathrm{~mL}$. Larutan diamati di bawah sinar UV $366 \mathrm{~nm}$; berfluoresensi kuning intensif, menunjukkan adanya flavonoid (Depkes RI, 1995).

\section{Pembuatan Larutan Uji Ekstrak daging lidah buaya}

Sebanyak 5 g ekstrak daging lidah buaya ditambah $25 \mathrm{~mL}$ etanol. Diaduk selama 24 jam menggunakan alat pengaduk pada kecepatan $200 \mathrm{rpm}$, kemudian disaring dan 
filtrat yang diperoleh ditambah etanol sampai 25 mL (Azizah dkk., 2014).

\section{Penetapan kadar flavonoid total}

Larutan blanko dibuat dengan mengganti larutan standar dengan etanol 0,5 $\mathrm{ml}$. Ditambahkan dengan 1,5 ml etanol 95\%, $0,1 \mathrm{ml}$ aluminium klorida (AlCl3) $10 \%, 0,1 \mathrm{ml}$ kalium asetat $1 \mathrm{M}$ dan ditambahkan akuades 2,8 ml. Setelah itu diinkubasi selama 30 menit pada suhu $25^{\circ} \mathrm{C}$. Setiap pengukuran serapan dibandingkan terhadap blanko. Larutan uji berisi $0,1 \mathrm{ml}$ ekstrak daging lidah buaya dipipet, kemudian ditambah etanol sampai 10 $\mathrm{ml}$ dalam labu ukur. Sejumlah 0,5 ml larutan kemudian ditambah dengan 1,5 ml etanol 95\% $0,1 \mathrm{ml}$ aluminium klorida (AlCl3) 10\%, 0,1 ml kalium asetat $1 \mathrm{M}$ dan ditambahkan akuades $2,8 \mathrm{ml}$. Setelah itu diinkubasi selama 30 menit pada suhu $25^{\circ}$ C. Serapan diukur pada $\lambda 434,2$ $\mathrm{nm}$ menggunakan spektrofotometri Uv - Vis. Pengujian dilakukan secara triplo.

\section{Pembuatan Sediaan}

Basis krim dibuat dengan cara fase minyak (cera alba, span 80, paraffin liquidum,propilpparaben/nipasol) dipindahkan dalam cawan penguap, dipanaskan diatas water bath dengan suhu $70^{\circ} \mathrm{C}$ sampai lebur. Fase air (metilparaben/nipagin,air) dipanaskan di atas hot plate dengan magnetic stirer pada suhu $70^{\circ} \mathrm{C}$ sampai melebur. Fase minyak ditambahkan ke fase air pencampuran dilakukan pada suhu yang sama $\left(60-70^{\circ} \mathrm{C}\right)$, diaduk menggunakan magnetic stirer sampai dingin dan terbentuk krim yang homogen setelah terbentuk masa krim, ekstrak kental air daging daun Aloe vera digerus dalam mortir, kemudian sedikit demi sedikit basis krim ditambahkan. Digerus pelan-pelan sampai homogen. Dilakukan evaluasi.

\section{HASIL DAN PEMBAHASAN}

\section{Standarisasi ekstrak}

Standarisai ekstrak daging daun lidah buaya meliputi pengujian penetapan susut pengeringan, kadar abu total, penetapan kadar abu tidak larut dalam asam, penetapan kadar sari yang larut dalam air, penetapan kadar sari yang larut dalam etanol dan skrining fitokimia.
Tabel 2. Hasil Standarisasi Ekstrak

Parameter

Hasil

\begin{tabular}{lc}
\hline Susut Pengeringan & $26,33 \%$ \\
Kadar Abu Total & $1,3 \%$ \\
Kadar abu tidak larut asam & $2,1 \%$ \\
Kadar Sari yang Larut dalam Air & $11,9 \%$ \\
Kadar Sari yang Larut dalam & $12,01 \%$. \\
\hline
\end{tabular}

\section{Susut Pengeringan}

Uji susut pengeringan bertujuan untuk mengetahui kandungan air pada suatu bahan. Uji susut pengeringan pada ekstrak aloe vera dengan dilakukan pemanasan berulang - ulang yaitu pemanasan 1 sampai 4. Nilai kadar susut pengeringan pada ekstrak aloe vera dapat dilihat pada persentase susut pengeringan pada bobot setelah pemanasan ke 4 yaitu 26,33\%. Hasil tersebut memenuhi persyaratan yaitu tidak lebih dari 94\% (Kemenkes RI, 2009).

\section{Uji Kadar Abu Total}

Pengujian kadar abu total dilakukan untuk mengetahui kadar abu dari ekstrak daging lidah buaya telah memenuhi parameter standar mutu yang telah ditetapkan. Kadar abu total yang diperoleh sebesar $1,3 \%$, dimana hasil ini sesuai dengan persyaratan Farmakope Herbal Indonesia tidak lebih dari 1,5\%

\section{Uji Kadar Abu Tidak Larut Asam}

Kadar abu tidak larut asam yang diperoleh sebesar 2,1\%. Hasil yang diperoleh memenuhi persyaratan kadar abu tidak larut asam sebesar 4,5\% (Kemenkes RI, 2009).

\section{Uji Kadar Sari Larut Dalam Air dan Larut Dalam Etanol}

Penetapan kadar sari larut air dilakukan untuk mengetahui persentase senyawa polar dan semi non polar sampai non polar pada ekstrak. Hasilnya merupakan perkiraan kasar senyawa-senyawa yang bersifat polar (larut air) dan senyawa-senyawa yang bersifat semi polar sampai non polar (larut etanol). 
Hasil standarisasi kadar sari larut air ekstrak aloe vera adalah $12 \%$, dimana hasil tersebut memenuhi syarat Farmakope Herbal Indonesia yaitu tidak kurang dari 11,3\%. Hasil standarisasi kadar sari larut etanol ekstrak aloe vera adalah $12,01 \%$, dimana hasil tersebut memenuhi syarat yaitu tidak kurang dari 2,3\% (Kemenkes RI, 2009).

\section{Skrining fitokimia ekstrak}

Skrining fitokimia yang dilakukan meliputi uji saponin, tanin dan flavonoid.

Tabel 3. Hasil Skrining Fitokimia

\begin{tabular}{|c|c|c|c|}
\hline $\begin{array}{l}\text { Skrining } \\
\text { fitokimia }\end{array}$ & Pustaka & Hasil & \\
\hline Flavonoid & $\begin{array}{l}\text { Fluoresensi } \\
\text { kuning } \\
\text { intensif } \\
\text { pada UV } \\
366 \mathrm{~nm}\end{array}$ & $\begin{array}{c}\text { Terdapat } \\
\text { fluoresensi } \\
\text { kuning } \\
\text { intensif } \\
\text { pada UV } \\
366 \mathrm{~nm}\end{array}$ & $(+)$ \\
\hline Tanin & $\begin{array}{l}\text { Terbentuk } \\
\text { warna } \\
\text { kecoklatan }\end{array}$ & $\begin{array}{c}\text { Terjadi } \\
\text { warna } \\
\text { kecoklatan }\end{array}$ & $(+)$ \\
\hline Saponin & $\begin{array}{c}\text { Ada busa } \\
\text { yang } \\
\text { bertahan } \pm \\
10 \text { menit } \\
\text { setinggi } 1 \text { - } \\
10 \mathrm{~cm}\end{array}$ & $\begin{array}{c}\text { Terbentuk } \\
\text { busa }\end{array}$ & $(+)$ \\
\hline
\end{tabular}

Hasil uji skrining fitokimia menunjukkan bahwa ekstrak air aloe vera mengandung golongan senyawa saponin dan tannin, flavonoid.

\section{Penetapan Kadar Flovonoid Total}

Pengujian kadar flavonoid total dilakukan untuk mengetahui kadar flavonoid yang terkandung dalam ekstrak daging lidah buaya karena flavonoid merupakan kandungan kimia yang berperan sebagai antiinflamasi pada luka bakar. Kadar flavonoid yang diperoleh sebesar 2,9\%. Hasil kadar flavonoid yang diperoleh memenuhi persyaratan literature yaitu tidak lebih dari 3,50\% (Depkes RI, 2008).

\section{Identifikasi Dengan FT-IR}

Identifikasi senyawa flavonoid ekstrak lidah buaya menggunakan FT-IR untuk melihat gugus fungsi pada sampel. Berikut spectrum inframerah ekstrak lidah buaya:

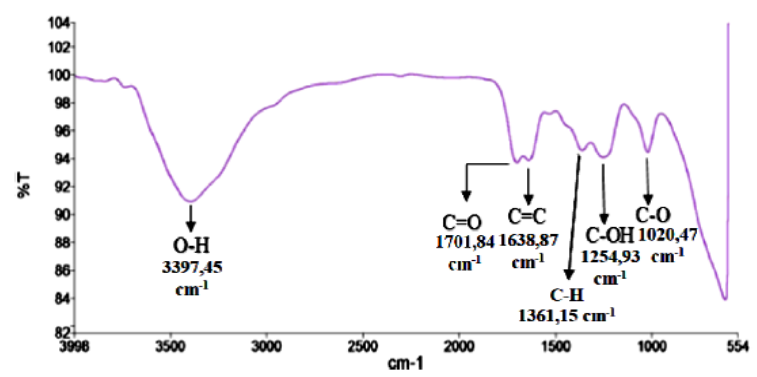

Gambar 1. Spektrum inframerah ekstrak lidah buaya

Hasil identifikasi senyawa flavonoid ekstrak lidah buaya menunjukan bahwa adanya serapan melebar pada daerah bilangan gelombang $3397,45 \mathrm{~cm}^{-1}$ yang diduga adalah serapan ulur dari guguh $\mathrm{O}-\mathrm{H}$. Gugus fungsi $\mathrm{C}=\mathrm{O}$ ditunjukkan pada bilangan gelombang $1701,84 \mathrm{~cm}^{-1}$. Serapan ulur $\mathrm{C}=\mathrm{C}$ aromatik muncul pada bilangan gelombang 1638,87 $\mathrm{cm}^{-1}$ didukung adanya serapan $\mathrm{C}-\mathrm{H}$ pada gelombang $1362,15 \mathrm{~cm}^{-1}$. Serapan lemah pada bilangan gelombang $1254,93 \mathrm{~cm}^{-1}$ yang diduga adalah serapan ulur dari gugus C-OH. Serapan tajam pada daerah bilangan gelombang $1020,47 \mathrm{~cm}^{-1}$ dengan pita lemah menunjukkan gugus C-O. Berdasarkan data tersebut diduga pada ekstrak lidah buaya menunjukan adanya gugus fungsi $\mathrm{O}-\mathrm{H}, \mathrm{C}=\mathrm{O}, \mathrm{C}=\mathrm{C}, \mathrm{C}-\mathrm{H}, \mathrm{C}-\mathrm{OH}$ dan $\mathrm{C}-\mathrm{O}$ menandakan bahwa ekstrak lidah buaya mengandung senyawa flavonoid.

\section{Evaluasi Sediaan Krim}

1. Uji Homogenitas yaitu terbentuk masa krim yang homogeny dan terdistribusi merata

2. Uji tipe emulsi yaitu pada sediaan krim ekstrak daging lidah buaya dengan tipe minyak dalam air

3. Uji daya lekat krim ekstrak daging lidah buaya yaitu memiliki waktu melekat 86 detik

4. Uji daya sebar krim ekstrar daging lidah buaya diperoleh tanpa beban $(\mathrm{P}=2,4 \mathrm{~cm}$, $\mathrm{L}=2,2 \mathrm{~cm})$, dengan beban 50 gram $(\mathrm{P}=$ $4,1 \mathrm{~cm}, \mathrm{~L}=4 \mathrm{~cm}$ ), dengan beban 100 gram $(\mathrm{P}=4,8 \mathrm{~cm}, \mathrm{~L}=4,7 \mathrm{~cm})$, dan dengan beban 50 gram $(\mathrm{P}=5,3 \mathrm{~cm}, \mathrm{~L}=$ $5,1 \mathrm{~cm}$ ) berarti krim ekstrak daging lidah buaya mampu menyebar dengan luas jika digunakan. 
5. Uji pH bertujuan untuk mengetahui apakah sediaan krim yang dibuat memiliki $\mathrm{pH}$ yang aman agar tidak mengiritasi kulit. pH kulit 4,5 - 6,5 (Tranggono,2007) Hasil uji pH diperoleh $\mathrm{pH}$ krim ekstrak daging lidah buaya memenuhi persyaratan yaitu sebesar 5,2.

6. Uji Viskositas.

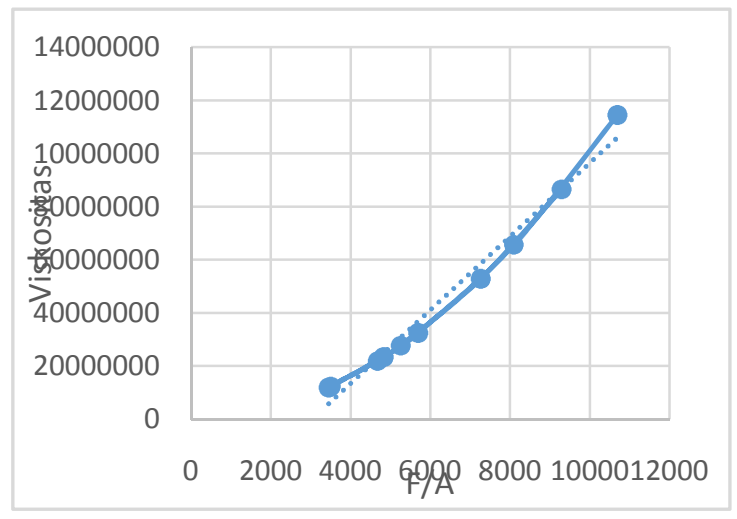

Gambar 2. Kurva hubungan viskositas dengan shearing stress

Rheogram yang diperoleh menunjukan bahwa sediaan yang telah direkonstitusi memiliki sifat alir pseudoplastik. Hal ini menunjukan bahwa sediaan yang dibuat memenuhi persyaratan sediaan farmasi yang mengikuti sifat alir Non-Newton pseudoplastik yaitu sifat alir yang akan menurun dengan meningkatnya kecepatan geser.

\section{SIMPULAN DAN SARAN}

\section{Simpulan}

Hasil standarisasi ekstrak daging lidah buaya menunjukan bahwa ekstrak daging lidah buaya memenuhi persyaratan parameter standar mutu ekstrak yang meliputi pengujian penetapan susut pengeringan, kadar abu total, penetapan kadar abu tidak larut dalam asam, penetapan kadar sari yang larut dalam air, penetapan kadar sari yang larut dalam etanol dan skrining fitokimia sehingga ekstrak daging lidah buaya dapat digunakan dalam pembuatan formulasi.

\section{Saran}

Diperlukan penelitian lebih lanjut mengenai optimasi formula krim lidah buaya untuk mendapatkan sediaan yang lebih baik dan dilakukan uji transport senyawa aktif secara in-vitro dan in-vivo serta dilakukan uji farmakologi antiluka bakar untuk sediaan krim lidah buaya.

\section{UCAPAN TERIMAKASIH}

Penulis mengucapkan terima kasih kepada bapak/ ibu laboran laboratorium farmasetika dasar Jurusan Farmasi Universitas Udayana, serta semua pihak yang turut membantu dalam menyelesaikan penelitian ini.

\section{DAFTAR PUSTAKA}

Atiyeh, B. S., M. Costagliola, S. N. Hayek, and S. A. Dibo. 2006. Effect of Silver on Burn Wound Infection Control and Healing: Review of The Literature. Burns. 33: 139.

Depkes RI. 1995a. Farmakope Indonesia Edisi $I V$. Departemen Kesehatan Republik Indonesia: Jakarta.

Harborne, J.B. 1987. Metode Fitokimia Penentuan Cara Modern Menganalisa tumbuhan . Bandung: ITB.

Kemenkes RI. 2009. Farmakope Herbal Indonesia. Jakarta: Kementerian Kesehatan Republik Indonesia.

Monafo, W. 2009. Initial Management of Burns. The New England Journal of Medicine, 335(21): 1-6.

Sari, L. R. O. K. 2006. Pemanfaatan Obat Tradisional dengan Pertimbangan Manfaat dan Keamanannya. Majalah Ilmu Kefarmasian, 3(1): 1-7.

Vijayalakshmi, R. and R. Ravindhran. 2012. Preliminary Comparative Phytochemical Screening of Root Extracts of Diospyrus ferrea (Wild.) Bakh and Aerva lanata (L.) Juss. Ex Schultes. Asian Journal of Plant Science and Research. 2(5): 583.

Wirya, L.P.A.I. 2012. Pemberian Ekstrak Air Lidah Buaya (Aloe vera L.) Memperbaiki Profil Lipid Darah Tikus Jantan WistardDengan Dislipidemia. Tesis. Denpasar: Pasca Sarjana Universitas Udayana. 